\title{
SHOULD ENGLISH LESSON BE ABOLISHED AT THE ELEMENTARY SCHOOL LEVEL? ENGLISH TEACHERS' AND PARENTS' DILEMMA OF THE 2013 CURRICULUM
}

\author{
Ahmad Kosasih $^{1}$, Dewi Listia Apriliyanti ${ }^{2}$ \\ ${ }^{1}$ IKIP Siliwangi \\ ${ }^{2}$ IKIP Siliwangi \\ ${ }^{1}$ ahmadkobaroya@gmail.com, ${ }^{2}$ apriliyanti.dl@ikipsiliwangi.ac.id
}

\begin{abstract}
The 2013 curriculum has removed English subjects at the elementary school level. This resulted in the emergence of a dilemma in both the teacher and parents of students. Therefore this research was carried out for analyzing the abolished English subject at the elementary school. This study is conducted to analyze the abolished English lesson at the elementary school level. A case study is applied as this research design. Key informants of this study were English teacher who taught at one of private elementary school in Bandung, and a parent of students. The researcher found a similarty between English teacher and parent of students', which is strongly disagree with the abolition English lesson in elementary school. Therefore, this study purposed alternative solution to resolve the abolished English lesson at the elementary school level in 2013 curriculum .
\end{abstract}

Keywords: Abolished, English Lesson, Curriculum 2013

\section{INTRODUCTION}

Curriculum has been generally described as a rule that government made for better education, this is the reason why curriculum is a dynamic document which is usually developed, revised, and/or replaced (Tegamuni \& Ugu, 2019). According to Gunawan \& Saputra (2020) various curricula and methods have been developed to improve students' ability to mastering English. The curriculum currently used in Indonesia is the 2013 curriculum that English has been removed for elementary school. This is quite unfortunate considering that English is very important. A global survey for the British Council in 2013, Shelagh Rixon in Bland (2015) in Cahyati, Parmawati, Atmawidjaja (2019) reports that English was being taught at every younger ages, putting pressure on educational resources across the world. According to Cameron (2001) cited in (Faidah et al., 2019) stated "Children can always do more than we think they can; they have huge learning potential, and the foreign language classroom does them a disservice if we do not exploit that potential". It can be concluded that learning language in the early age is good for children whether it is in first stage or in second stage. English as an official international language has become a necessity for us to learn. By learning and understanding English well, it will make easier for us to interact with foreigners, especially if we want to continue our education abroad. English is a language which one of its functions is for communicating. Additionally, according to Crystal (2005) cited in (Ota et al., 2018) said, English is used as an instrument of communication between countries principally in political, social, educational and economic development. Hence, English is an important to be learned, especially with the development of the increasingly demanding era of all people to be able to use English language (Santoso \& Andriyadi, 2019). Thus, English is taught and used as a foreign language in Indonesia. In addition, English should be treated as a habit from an early age. It is very important because by 
habituation, children will be trained in English conversations without ignoring the mother tongue (Indonesian and regional languages). Moreover, Wells (1991) cited in (Budiharto \& Affandi, 2018) said that the English language has been given to the students of elementary school, so that the students will not have difficulty in the next level of school.

In the KTSP curriculum, English has been taught from the kindergarten to the high school, with different level of materials. However, after the curriculum changed to the 2013 curriculum, the Indonesian Ministry of Education and Culture (Kemendikbud) issued a statement to remove English from elementary schools started in 2013/2014. This decision brought various comments from various circles, both from teachers as educators and from parents of the students.

Based on Indonesia regulation No.20 in 2003 about national education system of Indonesia cited in (Syamsia \& Tegamuni, 2018) curriculum is a set of plan and rules regarding to objective, content, and learning process and also method to be used as guideline of learning activity application to reach certain objectives. According ministry of education and culture in Indonesia (2014) cited in (Ayustina et al., 2018) said that In the implementation of Curriculum 2013, the word "teaching" switched to the word "learning how to learn", if in the previous curriculum, School-Based Curriculum, the teachers became the center of learning, here, it forces the students to be involved as the center in the process of learning. Regarding the importance of curriculum, thus, it can be argued that a sound curriculum is required to be implemented to achieve certain educational objective (Apsari, 2018).

Considering the usefulness of English as a lingua franca, this can certainly cause disquiet felt by English teachers in elementary schools and parents of students. Therefore, this paper will discuss the findings of an investigation carried out to explore the dilemmas that occur and then purpose solutions to resolve the dilemmas.

\section{METHOD}

This research applied descriptive qualitative method. According to Bogdan and Taylor cited in (Firdhani et al., 2018), the descriptive qualitative method is a research method that produces descriptive data in the form of written words or oral things that can be observed. Thus, the instruments of this research are observation and face to face interview. According to Burn cited in (Suryani et al., 2020), interviews and discussion are face-to face personal interaction, which generate data about the research issue and allow specific to discuss from other people perspective. Interview is used to gain a lot of information regarding to the difficulties teaching English in an elementary school related to the Curriculum 2013.

The research was conducted at one of Elementary private schools in Bandung. The researcher used open-ended interview to collect the data from an English teacher and a parent of student. Interview was used to ensure the trustworthiness of the data and to answer whether the teaching process can relate to the 2013 curriculum.

\section{RESULTS AND DISCUSSION}

\section{Results}

\section{Results}

\section{A. Teachers' and parents' point of view toward the abolished English lesson in elementary school level.}


Based on the investigation, the research found that there were similar points of view for both teachers and parents of students. English language teacher and parents argued that English lesson is needed in Elementary school as the basis of their foreign language knowledge. Besides, both teachers and parents contended that due to the advancement of education, being able to perform English is important for the students in the future by knowing the English basic knowledge since they were children.

This evidenced while doing face to face interviews. The evidences are as follow:The result are as follow :

Interviewer : "In your point of view, is English needed to be learned in elementary school?" Teacher : "I think English is actually needed in elementary school for it is a basic knowledge to build the skill of English even when the material is just such a vocabulary".

Parent : :Yes, English is needed for our children".

Interviewer : "What do you think about the abolished of English in elementary school?"

Teacher : "Unfortunately, English has been removed in elementary school. Well, I think children as the students are in the gold age to learn something, it's English to be exact".

Parent : It's kind of disappointing, because you know that nowadays almost everything used English in daily life".

\section{B. Student responds referring to English lesson based on explanation teachers' and parents'}

Interviever : "What are the responds of the students referring to English?"

Teacher : :"The students mostly are not into English because they use Bahasa Indonesia and Bahasa Sunda in daily conversation, so they think English is quite difficult. But they are really excited every time I come to the class to teach English. Then, I start from the basic knowledge for making English interesting for a student such as when I enter to the class I just simply say "Good morning" and they answer "Good morning" too as they respond, it indirectly teaches them about greeting”.

Parent :"The students do not feel any burden even though they think English is difficult".

Based on the results of the investigation, the research revealed that the students were very eager to learn English. Although, in their daily lives they only used Indonesian and Sundanese. In addition, students' parents revealed, when children learn English they feel unburdened by the lesson. This evidenced with teacher' explanation as follow;

"The students mostly are not into English because they use Bahasa Indonesia and Bahasa Sunda in daily conversation, so they think English is quite difficult. But they are really excited every time I come to the class to teach English. Then, I start from the basic knowledge for making English interesting for a student such as when I enter to the class I just simply say "Good morning" and they answer "Good morning" too as they respond, it indirectly teaches them about greeting". [Data description ET-01]. 


\section{Discussion}

English is not a required subject in elementary school yet the school still put it at the top of the subject for the goodness of their students in the future. One of the difficulties of teaching English in elementary school is the students do not use English because they use Bahasa Indonesia and Bahasa Sunda in daily conversation. However, the teacher keeps doing something new to make English for the goodness of their students in the future. It started from the basic knowledge for example, when the teacher enters to the class she just simply says "Good morning" and the children answer "Good morning" too as the respond, it indirectly teaches them about greeting in a very simple way.

The abolition of English lesson in elematary school is very unfortunate by teacher and parent, because it is verry supportive of chlildren's development in learning international language. One of solution for the parents' dilemma is that parent can do to support children in learning english is to take private english course at certain institution outside formal school. It will be improved the ability of children to perfom English language well.

\section{CONCLUSION}

Based on aforementioned research findings, this research has concluded three main aspects. First, The abolition of English subjects at the elementary level is considered inappropriate because this can be dilemmas to teachers and students in the future. Second, it is kind of disappointing English has been abolished in elementary school. The last, the solution for parents to increase student english ability is to enroll their children on private english course.

\section{ACKNOWLEDGMENTS}

I would like to express my sincere gratitude to the participants of this research namely English teachers of Bimasena School and parent of students who have given us support, so that we can complete and publish our article.

\section{REFERENCES}

Apsari, Y. (2018). Teachersâ€TM Problems And Solutions In Implementing Curriculum 2013. Acuity: Journal Of English Language Pedagogy, Literature And Culture, 3(1), 11-23.

Ayustina, K. P. P., Batan, I. G., \& Mahayanti, N. W. S. (2018). A Study of the Teachers' Roles in the Implementation of Scientific Approach in Teaching English At Smp Negeri 1 Singaraja. International Journal of Language and Literature, 2(3), 108-116. https://doi.org/10.23887/ijll.v2i3.16316

Budiharto, R. A., \& Affandi, A. (2018). The Roles of Teacher in Teaching English Based on School Based Curriculum at the VII A Grade of SMPN I Kadur Pamekasan. INTERAKSI, 13(1), 44-52.

Cahyati, S. S., Parmawati, A., \& Atmawidjaja, N. S. (2019). Optimizing English Teaching And Learning Process To Young Learners (A Case Study In Cimahi). Journal Of Educational Experts (JEE), 2(2), 107-114.

Faidah, R. T., Fauziati, E., \& Suparno. (2019). Teachers Beliefs on Multiple Intelligence Based English Teaching for Young Learners. Expose Journal, 8(1), 60-72.

Firdhani, A. R., Indrayani, L. M., \& Mahdi, S. (2018). the Use of Consonant Elision By Sri Mulyani During Her Interview Session With the Banker. ELTIN JOURNAL, Journal of 
English Language Teaching in Indonesia, 6(2), 53. https://doi.org/10.22460/eltin.v6i2.p53-58

Gunawan, S., \& Saputra, H. (2020). Problems and Teaching Solutions for Students' in Learning English. PROJECT (Professional Journal of English Education), 3(1), 59. https://doi.org/10.22460/project.v3i1.p59-64

Ota, M. K., Padmadewi, N. N., \& Santosa, M. H. (2018). Developing Communicative Learning Materials for Teaching English as a Foreign Language to Students of Elementary Teacher Study Program of Flores University of East Nusa Tenggara. Jurnal Pendidikan Bahasa Inggris Indonesia, 6(1), 1-12. https://doi.org/10.23887/jpbi.v6i1.2707

Santoso, I., \& Andriyadi, A. (2019). the Use of My Dictionary Application To Improve Students' Vocabulary Mastery. ELTIN JOURNAL, Journal of English Language Teaching in Indonesia, 7(1), 35. https://doi.org/10.22460/eltin.v7i1.p35-42

Suryani, L., Fitriani, S., \& Sopian, R. (2020). Teacher's Perspective and Problem Toward the Syllabus Content in Curriculum 2013. PROJECT (Professional Journal of English Education), 3(2), 244-251.

Syamsia, S., \& Tegamuni, S. (2018). The Implementation of Curriculum 2013 in English Subject at SMA Negeri in Ternate. Langua-Journal of Linguistics, Literature, and Language Education, I(1), 73-82. https://doi.org/https://doi.org/10.5281/zenodo.1443108

Tegamuni, S., \& Ugu, K. N. (2019). The Teacher's Problem in Implementing Curriculum 2013 at State Senior High School 3 of West Halmahera. Langua-Journal of Linguistics, Literature, and Language Education, 2(1), 33-38. https://doi.org/http://doi.org/10.5281/zenodo.2588114 